Bulletin of Pharmaceutical Sciences
Assiut University

\title{
HYPOGLYCEMIC AND HYPOLIPIDEMIC EFFECTS OF GINGER IMPROVE KIDNEY FUNCTION IN OBESE MALE RATS
}

\author{
Amira M. El-Noweihi ${ }^{1}$, NaglaTaha Elmelegy ${ }^{1}$, Sally M. Bakar ${ }^{1}$ and Shimaa Abd El-Nasser ${ }^{2 *}$ \\ ${ }^{1}$ Department of Medical Biochemistry, Faculty of Medicine, Assiut University, Egypt \\ ${ }^{2}$ Department of Biochemistry, Faculty of Pharmacy, South Valley University, Egypt
}

\begin{abstract}
Aside from being a social stigma, obesity is frequently associated with insulin resistance, in turn linked to development of type II diabetes, hypertension, hyperlipidemia, and atherosclerosis - the so-called metabolic syndrome.This study investigated the biochemical changes in serum urea and creatinine levels in obese male rats treated with aqueous ginger extract. Forty age-matched adult male wister rats (90-110) gm were divided into four groups of ten rats each: Group I, Control group; Group II: Obese group. Group III: Low ginger dose (200 mg/kg body weight) treated obese group; Group IV: High ginger dose (400 mg/kg body weight) treated obese group.The obese group exhibited hyperglycemia accompanied with increasing in serum levels of Triglycerides (TG), Low Density Lipoprotein Cholesterol (LDL-C), Total Cholesterol (TC) levels. On the other hand, there was a significant reduction in High Density Lipoprotein Cholesterol (HDL-C) level. Ginger was effective in lowering all previous mentioned biochemical parameters and HDL-C level was increased significantly. Serum urea and creatinine levels showed a significant increase in obese rats. Otherwise, obese rats treated with ginger at either dose revealed a significant decrease as compared to obese group. These results indicated that the hypoglycemic and hypolipidemic effects of aqueous ginger extract $(200,400 \mathrm{mg} / \mathrm{kg} /$ day $)$ could ameliorate obesity related kidney dysfunction.
\end{abstract}

\section{INTRODUCTION}

The global prevalence of obesity has been approximately 3-fold higher compared to $1975^{1}$ and is suggested to still rise in future ${ }^{2}$. Over the last three decades, body mass index (BMI) has increased worldwide by $0.4 \mathrm{~kg} \cdot \mathrm{m}^{-2}$ per decade ${ }^{3}$. According to World Health Organization (WHO), Obesity is defined as a profuse accumulation of fat caused by an imbalance in intake and consumption of energy accompanied by insufficient physical activity ${ }^{1}$.

Obesity may be associated with renal disease $^{4}$. It increases the incidence of predisposing factors of chronic kidney disease (CKD), like hypertension and diabetes ${ }^{5}$. Increased renal filtration occurs in obese individuals to meet the elevated metabolic demands of raised body weight ${ }^{4}$. The hyperintraglomerular pressure can destroy the kidney and increase the risk of developing CKD by time $^{6}$.

Ginger (Zingiber officinale family, Zingiberacae) is one of the most widely consumed spices worldwide. It was reported that ginger also has a therapeutic benefits in cancer, clotting, inflammation, and analgesic activities $^{7}$. The renoprotective effects of ginger have also been reported in the animal models of ischemia/reperfusion ${ }^{8}$, and streptozotocin ${ }^{9}$ induced renal injuries. However, the efficacy of ginger on the metabolic syndrome-associated kidney damages in HFSD-induced obese rats remains unknown. In the present study, the impact of ginger on HFSD-induced kidney injury in rats was investigated.

Received in 18/4/2019 \& Accepted in 5/5/2019 


\section{MATERIALS AND METHODS}

\section{Experimental animals}

Forty age-matched adult male wister rats with initial body weights ranging from 90-110 gm were chosen as an animal model for this study. They were obtained from animal house, Faculty of Medicine, Assiut University, Assiut, Egypt. They were maintained on a balanced diet of bread with water supply till the start of experiment. The experiment ran according to Institutional Animal Ethic Committee guidelines for care and use of laboratory animals ${ }^{10}$.

\section{Preparation of aqueous ginger extract}

Aqueous ginger extract was prepared as reported by Al-Amin et al. ${ }^{11}$. Ginger powder was purchased from Dop Organik Company for Pharmaceutical Industries, Turkey.

\section{Induction of obesity}

After two weeks of acclimatization, the rats were randomly divided into: Group I: Control group (10 rats), they were fed a standard diet throughout the experimental period. The remaining 30 rats were daily fed a high fat, sucrose diet (HFSD) which was composed of $55 \%$ standard diet, $15 \%$ beef tallow, 20\% sucrose, $5 \%$ roasted peanuts, $5 \%$ milk powder, $5 \%$ egg, $3 \%$ sesame oil and $2 \%$ $\mathrm{NaCl}$ as reported by Ragab et al. (2015) ${ }^{12}$. After eight weeks, according to BMI, oral daily administration of aqueous ginger extract was started in concomitant with continuation of HFSD feeding for another eight weeks as follows; Group II: Obese group (10 rats), they were left untreated. Group III: Low ginger dose treated obese group (LGD, 10 rats), they were received aqueous ginger extract $(200 \mathrm{mg} / \mathrm{kg}$ body weight). Group IV: High ginger dose treated obese group (HGD, 10 rats), they were received aqueous ginger extract $(400 \mathrm{mg} / \mathrm{kg}$ body weight) according to Bhandari et al. ${ }^{13}$.

Rats' body weight (BW) was measured at the end of experiment and BMI was calculated as follows:

$$
\mathrm{BMI}=\text { body weight }(\mathrm{kg}) / \text { length }^{2}\left(\mathrm{~m}^{2}\right) .
$$

\section{Sample collection}

At the end of this period (16 weeks), animals fasted overnight; venous blood samples $(3-5 \mathrm{ml})$ were taken from the retroorbital sinus via glass capillaries under light anesthesia with diethyl ether to reduce animals' excitability $^{14}$. These samples were put in Wassermann empty tube, left to clot at room temperature for $30 \mathrm{~min}$ then centrifuged at $3000 \mathrm{rpm}$ for $10 \mathrm{~min}$, then the serum was separated immediately and divided into aliquots for the measurement of serum fasting glucose, the lipid profile parameters, urea and creatinine levels.

\section{RESULTS AND DISCUSSION}

\section{Results}

Effect of oral daily administration of aqueous ginger extract $(200,400 \mathrm{mg} / \mathrm{kg}$ body weight) on body weight, BMI, serum glucose and parameters of lipid profile in obese male rats

Obese group showed a significant increase in body weight, BMI, and the mean serum levels of glucose, TC, TG, and LDL-C as compared to those of control group ( $p<0.001$, Table 1, Fig. 1). It also showed a significant decrease in the mean serum level of HLD-C as compared to that of control group ( $\mathrm{p}<0.001$, Table 1, Fig. 1). Also, treatment of rats with $200 \mathrm{mg} / \mathrm{kg} / \mathrm{day}$ ginger extract orally for 8 weeks produced a significant decrease in body weight, BMI, and the mean serum levels of glucose, TC, TG, and LDL-C as compared to those of obese group ( $p<0.001$, Table 1, Fig. 1) and a significant increase in the mean serum level of HLD-C as compared to that of obese group ( $\mathrm{p}<0.001$, Table 1, Fig. 1). Moreover, the daily administration of $400 \mathrm{mg} / \mathrm{kg}$ ginger extract produced a significant decrease in body weight, and the mean serum levels of glucose, TC, TG, and LDL-C as compared to those of obese and LGD treated obese groups $(\mathrm{p}<0.001$, Table 1, Fig. 1), while, BMI showed a significant decrease as compared to that of obese group ( $p<0.001$, Table 1, Fig. 1) and no sigificant change as compared to LGD treated obese group. It also showed a highly significant increase in the mean serum level of HLD-C as compared to that of obese and LGD treated obese groups ( $\mathrm{p}<0.001$, Table 1, Fig. 1). 
Table 1: Effect of oral daily administration of aqueous ginger extract $(200,400 \mathrm{mg} / \mathrm{kg})$ on body weight, BMI, serum glucose and parameters of lipid profile in obese male rats.

\begin{tabular}{|c|c|c|c|c|}
\hline Group & $\begin{array}{l}\text { Control group } \\
n=10\end{array}$ & $\begin{array}{l}\text { Obese group } \\
n=10\end{array}$ & $\begin{array}{l}\text { LGD treated } \\
\text { obese group } \\
n=10\end{array}$ & $\begin{array}{c}\text { HGD treated } \\
\text { obese group } \\
n=10\end{array}$ \\
\hline $\begin{array}{l}\text { Body Weight } \\
\text { (gm) }\end{array}$ & $175.3 \pm 18.54$ & $\begin{array}{c}374.9 \pm 32.49 \\
\mathrm{a}^{* * *}\end{array}$ & $\begin{array}{c}270.9 \pm 13.07 \\
a^{* * *} \\
b^{* * *}\end{array}$ & $\begin{array}{c}207.7 \pm 16.15 \\
\mathrm{a}^{* * *} \\
\mathrm{~b}^{* * *} \\
\mathrm{c}^{* * *}\end{array}$ \\
\hline $\begin{array}{c}\mathrm{BMI} \\
\left(\mathrm{Kg} / \mathrm{m}^{2}\right)\end{array}$ & $1.80 \pm 0.55$ & $\begin{array}{c}7.34 \pm 1.30 \\
a^{* * *}\end{array}$ & $\begin{array}{c}2.36 \pm 0.65 \\
\mathrm{a}^{\mathrm{ns}} \\
\mathrm{b}^{* * *}\end{array}$ & $\begin{array}{c}2.66 \pm 0.91 \\
\mathrm{a}^{\mathrm{ns}} \\
\mathrm{b}^{* * *} \\
\mathrm{c}^{\mathrm{ns}} \\
\end{array}$ \\
\hline $\begin{array}{c}\text { Fasting blood } \\
\text { glucose level } \\
(\mathrm{mmol} / \mathrm{l})\end{array}$ & $5.34 \pm 0.33$ & $\begin{array}{c}8.42 \pm 0.67 \\
a^{* * *}\end{array}$ & $\begin{array}{c}7.28 \pm 0.48 \\
\mathrm{a}^{* * *} \\
\mathrm{~b} * * *\end{array}$ & $\begin{array}{c}6.43 \pm 0.40 \\
\mathrm{a}^{* * *} \\
\mathrm{~b}^{* * *} \\
\mathrm{c}^{* *}\end{array}$ \\
\hline $\begin{array}{c}\mathrm{TC} \\
(\mathrm{mg} / \mathrm{dl})\end{array}$ & $101.99 \pm 22.55$ & $\begin{array}{c}207.14 \pm 42.76 \\
a^{* * *}\end{array}$ & $\begin{array}{c}137.80 \pm 12.98 \\
a^{* * *} \\
b^{* * *}\end{array}$ & $\begin{array}{c}109.02 \pm 6.80 \\
\mathrm{a}^{\mathrm{ns}} \\
\mathrm{b}^{* * *} \\
\mathrm{c}^{* * *}\end{array}$ \\
\hline $\begin{array}{c}\mathrm{TG} \\
(\mathrm{mg} / \mathrm{dl})\end{array}$ & $77.35 \pm 46.43$ & $\begin{array}{c}256.93 \pm 67.47 \\
\mathrm{a} * * *\end{array}$ & $\begin{array}{c}173.72 \pm 16.79 \\
a^{* * *} \\
b^{* * *}\end{array}$ & $\begin{array}{c}113.78 \pm 17.64 \\
\mathrm{a}^{* * *} \\
\mathrm{~b}^{* * *} \\
\mathrm{c}^{* * *}\end{array}$ \\
\hline $\begin{array}{l}\text { HDL-C } \\
(\mathrm{mg} / \mathrm{dl})\end{array}$ & $61.45 \pm 17.54$ & $\begin{array}{c}15.52 \pm 3.23 \\
\mathrm{a}^{* * *}\end{array}$ & $\begin{array}{c}29.38 \pm 6.27 \\
\mathrm{a}^{* * *} \\
\mathrm{~b}^{* * *}\end{array}$ & $\begin{array}{c}44.26 \pm 5.64 \\
\mathrm{a}^{* * *} \\
\mathrm{~b}^{* * *} \\
\mathrm{c}^{* * *}\end{array}$ \\
\hline $\begin{array}{l}\text { LDL-C } \\
(\mathrm{mg} / \mathrm{dl})\end{array}$ & $25.07 \pm 28.97$ & $\begin{array}{c}140.23 \pm 32.62 \\
\mathrm{a}^{* * *}\end{array}$ & $\begin{array}{c}73.68 \pm 15.43 \\
a^{* * *} \\
b^{* * *}\end{array}$ & $\begin{array}{c}2.01 \pm 8.56 \\
\mathrm{a}^{* * *} \\
\mathrm{~b}^{* * *} \\
\mathrm{c}^{* * *} \\
\end{array}$ \\
\hline
\end{tabular}

BMI, body mass index; TC, total cholesterol; TG, triglycerides; HDL-C, high density lipoprotein cholesterol; LDL-C, low density lipoprotein cholesterol; LGD, low ginger dose; HGD, high ginger dose.

Results were expressed by Mean \pm S.D.

a compared to control group.

b compared to obese group.

c compared to LGD treated obese group.

$* \mathrm{P}<0.05, * * \mathrm{P}<0.01, * * * \mathrm{P}<0.001$. 


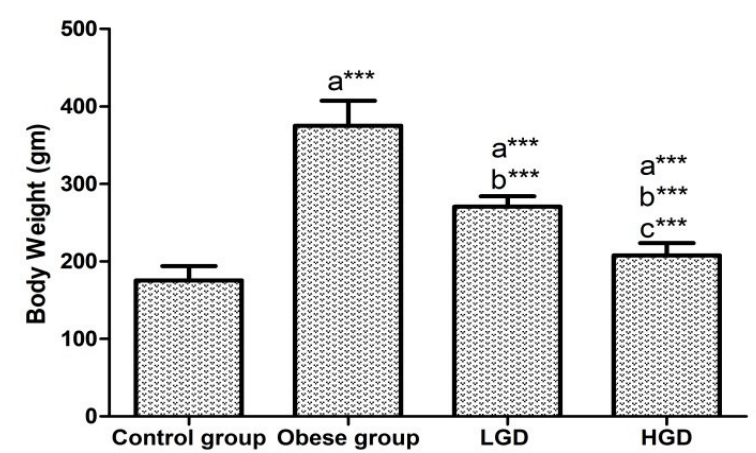

a) Body weight

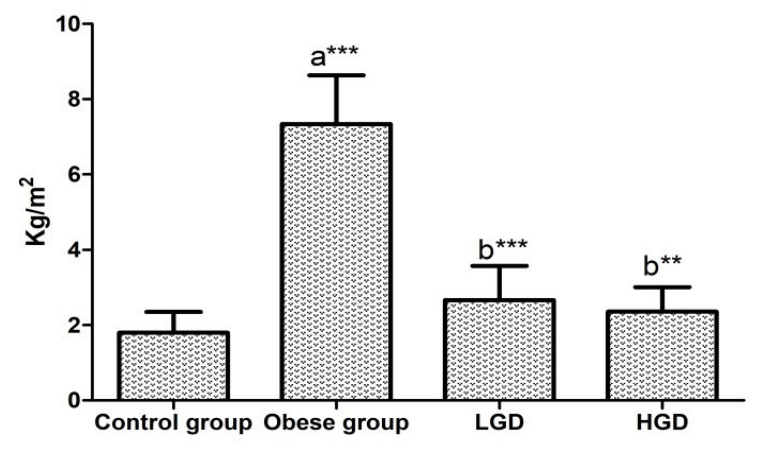

b) BMI

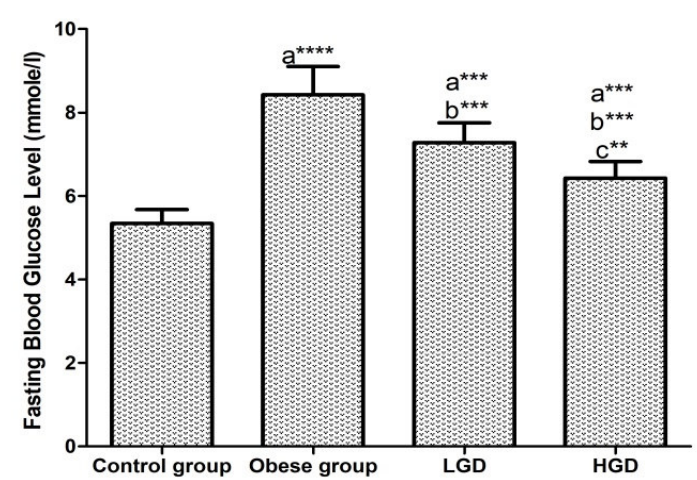

c) Fasting blood glucose level

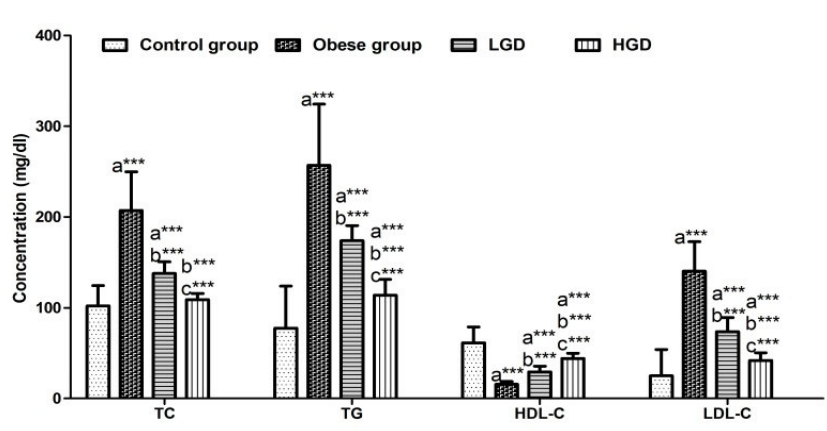

d) Serum parameters of lipid profile

Fig. 1: Effect of oral daily administration of aqueous ginger extract $(200,400 \mathrm{mg} / \mathrm{kg})$ on body weight, BMI, serum glucose and parameters of lipid profile in obese male rats.

BMI, body mass index; TC, total cholesterol; TG, triglycerides; HDL-C, high density lipoprotein cholesterol; LDL-C, low density lipoprotein cholesterol; LGD, low ginger dose; HGD, high ginger dose.

Results were expressed by Mean \pm S.D.

a compared to control group.

b compared to obese group.

c compared to LGD treated obese group.

$* \mathrm{P}<0.05, * * \mathrm{P}<0.01, * * * \mathrm{P}<0.001$.

Effect of oral daily administration of aqueous ginger extract $(200,400 \mathrm{mg} / \mathrm{kg}$ body weight) on serum levels of urea and creatinine in obese male rats

Obese group showed a highly significant increase in the mean serum levels of urea and creatinine as compared to those of control group ( $\mathrm{p}<0.001$, Table 2, Fig. 2). Treatment of rats with $200 \mathrm{mg} / \mathrm{kg} /$ day ginger extract orally for 8 weeks produced a highly significant decrease in the mean serum level of creatinine as compared to those of obese group $(\mathrm{p}<0.001$, Table 2, Fig. 2), while, the mean serum level of urea was showed no significant difference as compared to that of obese group. Also, administration of $400 \mathrm{mg} / \mathrm{kg}$ ginger extract produced a significant decrease in the mean serum levels of urea and creatinine as compared to those of obese and LGD treated obese groups $(\mathrm{p}<0.01$, Table 2, Fig. 2). 
Table 2: Effect of oral daily administration of aqueous ginger extract $(200,400 \mathrm{mg} / \mathrm{kg})$ on serum levels of urea and creatinine in obese male rats.

\begin{tabular}{|c|c|c|c|c|}
\hline Group & $\begin{array}{l}\text { Control group } \\
\qquad n=10\end{array}$ & $\begin{array}{c}\text { Obese group } \\
n=10\end{array}$ & $\begin{array}{c}\text { LGD treated } \\
\text { obese group } \\
n=10\end{array}$ & $\begin{array}{c}\begin{array}{c}\text { HGD treated } \\
\text { obese group } \\
n=10\end{array} \\
\text { n }\end{array}$ \\
\hline $\begin{array}{l}\text { Urea } \\
(\mathrm{mg} / \mathrm{dl})\end{array}$ & $31 . \pm 5.48$ & $\begin{array}{c}46.31 \pm 9.21 \\
\mathrm{a}^{* * *}\end{array}$ & $\begin{array}{c}47.50 \pm 7.46 \\
\mathrm{a}^{* * *} \\
\mathrm{~b}^{\mathrm{ns}}\end{array}$ & $\begin{array}{c}35.40 \pm 4.18 \\
\mathrm{a}^{\mathrm{ns}} \\
\mathrm{b}^{* *} \\
\mathrm{c}^{* *} \\
\end{array}$ \\
\hline $\begin{array}{l}\text { Creatinine } \\
(\mathrm{mg} / \mathrm{dl})\end{array}$ & $0.52 \pm 0.10$ & $\begin{array}{c}0.84 \pm 0.05 \\
a^{* * *}\end{array}$ & $\begin{array}{c}0.74 \pm 0.05 \\
\mathrm{a}^{* * *} \\
\mathrm{~b}^{* *}\end{array}$ & $\begin{array}{c}0.62 \pm 0.04 \\
\mathrm{a}^{* *} \\
\mathrm{~b}^{* *} \\
\mathrm{c}^{* *}\end{array}$ \\
\hline
\end{tabular}

LGD, low ginger dose; HGD, high ginger dose.

Results were expressed by Mean \pm S.D.

a compared to control group.

b compared to obese group.

c compared to LGD treated obese group.

$* \mathrm{P}<0.05, * * \mathrm{P}<0.01, * * * \mathrm{P}<0.001$.

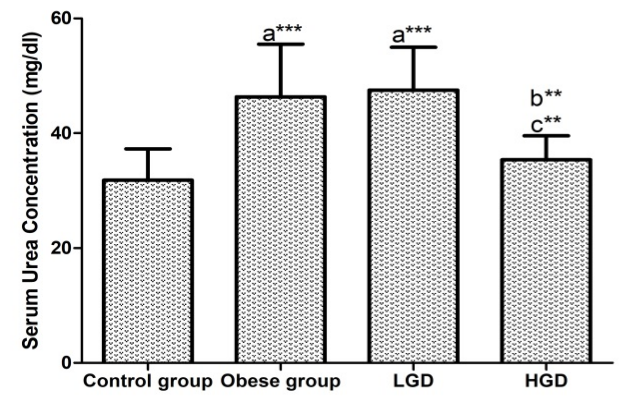

a) Serum Urea Concentration

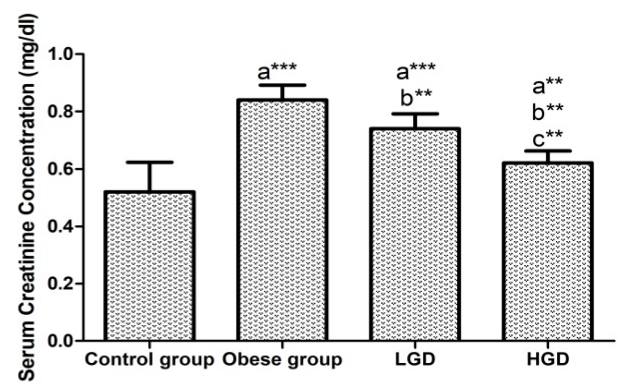

b) Serum Creatinine Concentration

Fig. 2: Effect of oral daily administration of aqueous ginger extract $(200,400 \mathrm{mg} / \mathrm{kg})$ on serum levels of urea and creatinine in obese male rats.

Results were expressed by Mean \pm S.D.

a compared to control group.

b compared to obese group.

c compared to LGD treated obese group.

$* \mathrm{P}<0.05, * * \mathrm{P}<0.01, * * * \mathrm{P}<0.001$.

\section{Discussion}

Obesity is a serious nutritional problem, as it increases the risk of morbidity from several pathologies ${ }^{15}$. Obesity, especially the central or visceral type, is a predisposing factor for the development of type II diabetes mellitus, hypertension, and cardiovascular disease $(\mathrm{CVD})^{16}$. Recently, dietary polyphenols and their roles in the prevention of obesity and obesity-related chronic and metabolic diseases have received research attention. Whether a spice, vegetable, or traditional medicine, ginger is well-known for its therapeutic effects on obesity ${ }^{17}$. In the present study, the effect of aqueous ginger extract on some biochemical parameters in obese male rats was investigated.

Rats fed a HFSD showed visceral adiposity, hyperglycemia, dyslipidemia, 
hyperinsulinemia, oxidative stress, metainflammation, hepatic and renal dysfunction, which are distinctly linked with human obesity $^{18}$. Excessive growth of adipose tissue results in obesity, which includes two growth mechanisms: hyperplastic (an increase in cell number) and hypertrophic (an increase in cell size $)^{19}$. In the present study, obese rats showed a significant increase in body weight and body mass index. The increased in body weight and body mass index found in HFSD fed rats might be due to the consumption of a diet rich in energy. These findings are in agreement with Liu et al. and Lomba et al. ${ }^{20 \& 21}$ who stated that HFSD induced weight gain and obesity.

In the present study, treatment with ginger showed a significant decrease in body weight and BMI. These results are in consistence with Ebrahimzadeh et al., Saravanan et al. and Lu et $a l .{ }^{22-24}$. Ginger suppresses body weight gain induced by HFD feeding via the regulation of fatty acid metabolism ${ }^{25}$ and inhibiting adipocyte differentiation ${ }^{26 \& 27}$. In adipocytes, PPAR- $\gamma$ and C/EBP- $\alpha$ are the key transcription regulator genes involved in adipogenesis ${ }^{28 \& 29}$. Recent studies indicated that PPARs are the major mediators of the anti-obesity and antidiabetic effects of ginger and its constituent compounds $^{30 \& 31}$. 6-Shogaol reduced the expression of PPAR- $\gamma$-associated genes and reduced adipogenesis in the cell $\operatorname{line}^{32}$. However, 6-gingerol could inhibit adipocyte differentiation by attenuating the Akt/GSK-3 $\beta$ pathway $^{33}$ and activating the $\mathrm{Wnt} / \beta$-catenin signaling pathway ${ }^{34}$.

In the present study, the obese rats showed mild hyperglycemia as compared to control group. HFSD has been shown to induce mild hyperglycemia by different mechanisms but considered mainly through the Randle or glucose-fatty acid cycle which is a biochemical mechanism involving the competition between glucose and fatty acids for their oxidation and uptake in muscle and adipose tissue ${ }^{35}$. Inflammation also contributes to the insulin signaling activity in adipocytes and hepatocytes through inhibition of insulin binding to its receptor, receptor phosphorylation, tyrosine kinase activity, and phosphorylation of IRSs ${ }^{36}$. These findings are in agreement with Liang et $a l^{37}$ and Kothari et al. ${ }^{38}$.

In the present study, ginger treated obese group showed a significant decrease in fasting blood glucose as compared to obese group. These finding could by explained by the study of Zhu et al. who found that ginger promotes insulin sensitivity ${ }^{39}$, thus lowering insulin resistance in obese rats, possibly by regulating the cell energy metabolism or reducing free fatty $\operatorname{acids}^{23}$. Ginger has been reported to increase the activity of hepatic glycolytic enzymes, including glucokinase, phosphofructokinase and pyruvate kinase. Ginger increased peripheral glucose utilization and decreased gluconeogenesis in the liver through its insulin mimetic effect ${ }^{40}$. These results are in consistence with Maharlouei et al., Iranloye et al. and Silveira et al. ${ }^{41-43}$.

HFSD supplementation resulted in dyslipidemic changes; increasing in serum TG, TC and LDL-C levels and decreasing in serum level of HDL-C ${ }^{44}$. High levels of TC, TG, LDL-C are the risk factor for $\mathrm{CVD}^{45}$. The alteration of lipid profile induced by HFSD might be caused by the activation of gastric lipases, intestinal fat absorption and the lipolysis. Also, impaired insulin action is associated with an over-supply of lipids. Diminished hepatic and muscular uptake of glucose produced hyperlipidemia due to increased fat mobilization from adipose tissue and resistance to the anti-lipolytic actions of insulin ${ }^{46}$. In the present study, supplementation of HFSD increased the lipid profile in plasma of experimental rats. These findings are in agreement withYamamoto et al. $^{47}$.

In the current study, ginger treated obese rats showed a significant reduction TG, TC and LDL-C levels and increase in serum level of HDL-C as compared to obese group. The suppression of plasma lipids by ginger may result from the reduction of the absorption of fat and cholesterol by inhibiting the activity of pancreatic lipase $^{23}$. Consistent with this study, studies reported that the ginger extracts produced a significant reduction of $\mathrm{TC}, \mathrm{TG}$, and LDL-C levels when compared to different models of obese rats ${ }^{11 \& 48-50}$.

In addition, recent studies have identified oxidative stress as a key player in obesity associated kidney dysfunction ${ }^{51}$. RosasVillegas et al., indicated that the exposure to HFSD, rats promotes the antioxidant system depression due to the increase of lipid peroxidation and decrease of GSH amount in the kidneys ${ }^{52}$. In the present study, obese rats 
showed a significant increase in serum creatinine and urea levels. Increased creatinine and urea levels indicate a lower degree of pore shrinkage due to cell proliferation and fibrosis of renal tubules ${ }^{53}$. The mechanism through which HFSD induced cell proliferation and fibrosis is not fully understood.

Accordingly, if HFSD consumption induces some functional abnormalities in kidneys through hyperglycemia and hyperlipidemia, as confirmed by present study and some previous ones, the effect of ginger supplementation on these abnormalities will be decreased. In the present study, Ginger treated obese rats showed a significant reduction in serum urea and creatinine. In agreement with Tzang et al., Gabr et al. and Mehradad et al. ${ }^{9 \&}$ $54 \& 55$ who stated that ginger and its active component improves obesity associated kidney dysfunction.

In Conclusion, The current study has demonstrated that ginger has protective effects on obesity and obesity-related chronic kidney diseases through its hypoglycemic and hypolipidemic effects.

\section{REFERENCES}

1- WHO. Obesity and Overweight factsheet from the WHO, Health (2017).

2- T. Kelly, W. Yang, C-S. Chen, K. Reynolds and J. He., "Global burden of obesity in 2005 and projections to 2030", Int. J. Obes., 32 (9), 1431 (2008).

3- T. A. A. Rahman, E. M. Mahfouz and E. S. Mohammed, "Prevalence and comorbidities of overweight and obesity among elderly population residing a rural community, Minia, Egypt.", EJCM, 30 (4), (2012).

4- C. P. Kovesdy, S. L. Furth, C. Zoccali and C. World Kidney Day Steering, "Obesity and Kidney Disease: Hidden Consequences of the Epidemic", CJKHD, 4, 2054358117698669- (2017).

5- J. P. Lea and S. B. Nicholas, "Diabetes mellitus and hypertension: Key risk factors for kidney disease", J. Natl. Med. Assoc., 94 (8 Suppl), 7S-15S (2002).

6- P. Palatini, "Glomerular hyperfiltration: A marker of early renal damage in prediabetes and pre-hypertension", Nephrol. Dial. Transplant., 27 (5), 1708-14 (2012).
7- Y. Li, V. H. Tran, C. C. Duke and B. D. Roufogalis, "Preventive and Protective Properties of Zingiber officinale (Ginger) in Diabetes Mellitus, Diabetic Complications, and Associated Lipid and Other Metabolic Disorders", A Brief Review, Evid. Based Complement. Alternat. Med., 2012, 516870 (2012).

8- E. Uz, O. F. Karatas, E. Mete, R. Bayrak, O. Bayrak, A. F. Atmaca, et al., "The effect of dietary ginger (Zingiber officinals Rosc) on renal ischemia/reperfusion injury in rat kidneys", Renal Failure, 31 (4), 251-60 (2009) .

9- T-F. Tzeng, S-S. Liou, C. J. Chang and IM. Liu, "Zerumbone, a tropical ginger sesquiterpene, ameliorates streptozotocininduced diabetic nephropathy in rats by reducing the hyperglycemia-induced inflammatory response", Nutr. \& Metab., 10 (1), 64 (2013).

10- A. P. Association, "Guidelines for ethical conduct in the care and use of animals", $J$. Exp. Anal. Behav., 45 (2), 127 (1986).

11- Z. M. Al-Amin, M. Thomson, K. K. AlQattan, R. Peltonen-Shalaby and M. Ali, "Anti-diabetic and hypolipidaemic properties of ginger (Zingiber officinale) in streptozotocin-induced diabetic rats", Br. J. Nutr., 96 (4), 660-6 (2006).

12- S. M. Ragab, S. K. A. Elghaffar, T. H. ElMetwally, G. Badr, M. H. Mahmoud and H. M. Omar, "Effect of a high fat, high sucrose diet on the promotion of nonalcoholic fatty liver disease in male rats: The ameliorative role of three natural compounds", Lipids Health Dis., 14 (1), 83 (2015).

13- U. Bhandari and K. Pillai, "Effect of ethanolic extract of Zingiber officinale on dyslipidaemia in diabetic rats", $\boldsymbol{J}$. Ethnopharmacol., 97 (2), 227-30 (2005).

14- S. H. Stone, "Method for obtaining venous blood from the orbital sinus of the rat or mouse", Science, 119 (3081), 100 (1954).

15- M. Abdelaal, C. W. le Roux and N. G. Docherty, "Morbidity and mortality associated with obesity", Ann. Transl. Med., 5 (7), (2017). 
16- K. G. M. M. Alberti, P. Zimmet and J. Shaw, "Metabolic syndrome- a new world-wide definition. A. consensus statement from the international diabetes federation", Diabetic Med., 23 (5), 469-80 (2006).

17- W. Si, Y. P. Chen, J. Zhang, Z-Y. Chen and H. Y. Chung, "Antioxidant activities of ginger extract and its constituents toward lipids", Food Chem., 239, 1117 25 (2018).

18- E. Molinar-Toribio, E. Fuguet, S. RamosRomero, N. Taltavull, L. Méndez, M. R. Nogués, et al, "A high-fat high-sucrose diet affects the long-term metabolic fate of grape proanthocyanidins in rats", "Eur. $\boldsymbol{J}$. Nutr., 57 (1), 339-49 (2018).

19- P. Björntorp and L. Sjöström, "Number and size of adipose tissue fat cells in relation to metabolism in human obesity", Metabolism, 20 (7), 703-13 (1971).

20- B-H. Liu, Y. Lin, Y-C. Wang, C-W. Huang, C-C. Chen, S. Wu, et al, "Porcine Adiponectin Receptor 1 Transgene Resists High-fat/Sucrose Diet-Induced Weight Gain, Hepatosteatosis and Insulin Resistance in Mice", Exp. Anim., 347-60 (2013).

21- A. Lomba, F. I. Milagro, D. F. GarcíaDíaz, A. Marti, J. Campión and J. A. Martínez, "Obesity induced by a pair-fed high fat sucrose diet: Methylation and expression pattern of genes related to energy homeostasis", Lipids Health Dis., 9, 60 (2010).

22- V. Ebrahimzadeh Attari, A. Malek Mahdavi, Z. Javadivala, S. Mahluji, S. Zununi Vahed and A. Ostadrahimi, "A systematic review of the anti-obesity and weight lowering effect of ginger (Zingiber officinale Roscoe) and its mechanisms of action", Phytother. Res., 32 (4), 577-85 (2018).

23- G. Saravanan, P. Ponmurugan, M. A. Deepa and B. Senthilkumar, "Anti-obesity action of gingerol: Effect on lipid profile, insulin, leptin, amylase and lipase in male obese rats induced by a high-fat diet", $J$. Sci. Food Agric., 94 (14), 2972-7 (2014).

24- M. Lu, Y. Cao, J. Xiao, M. Song and CT. Ho, "Molecular mechanisms of the antiobesity effect of bioactive ingredients in common spices: A review", Food Funct., 9 (9), 4569-81 (2018).

25- S. Suk, G. T. Kwon, E. Lee, W. J. Jang, H. Yang, J. H. Kim, et al., "Gingerenone A, a polyphenol present in ginger, suppresses obesity and adipose tissue inflammation in high-fat diet-fed mice", Mol. Nutr. Food Res., 61 (10), 1700139 (2017).

26- M. P. Rani, M. S. Krishna, K. P. Padmakumari, K. G. Raghu and A. Sundaresan, "Zingiber officinale extract exhibits antidiabetic potential via modulating glucose uptake, protein glycation and inhibiting adipocyte differentiation: An in vitro study", J. Sci. Food Agric., 92 (9), 1948-55 (2012).

27- T. F. Tzeng, C. J. Chang and I. M. Liu, "6Gingerol inhibits rosiglitazone-induced adipogenesis in 3T3-L1 adipocytes", Phytother. Res., 28 (2), 187-92 (2014).

28- U. A. White and J. M. Stephens, "Transcriptional factors that promote formation of white adipose tissue", $\mathbf{M o l}$. Cell. Endocrinol., 318 (1-2), 10-4 (2010).

29- A. T. Ali, W. E. Hochfeld, R. Myburgh and M. S. Pepper, "Adipocyte and adipogenesis", Eur. J. Cell Biol., 92 (6-7), 229-36 (2013).

30- J. Wang, W. Ke, R. Bao, X. Hu and F. Chen, "Beneficial effects of ginger Zingiber officinale Roscoe on obesity and metabolic syndrome: A review", Ann. NY Acad. Sci., 1398 (1), 83-98 (2017).

31- K. Misawa, K. Hashizume, M. Yamamoto, Y. Minegishi, T. Hase and A. Shimotoyodome, "Ginger extract prevents high-fat diet-induced obesity in mice via activation of the peroxisome proliferatoractivated receptor $\delta$ pathway", J. Nutr. Biochem., 26 (10), 1058-67 (2015).

32- S. Suk, S. G. Seo, J. G. Yu, H. Yang, E. Jeong, Y. J. Jang, et al., "A Bioactive Constituent of Ginger, 6-Shogaol, Prevents Adipogenesis and Stimulates Lipolysis in 3T3-L1 Adipocytes", J. Food Biochem., 40 (1), 84-90 (2016).

33- T-F. Tzeng and I-M. Liu, "6-Gingerol prevents adipogenesis and the accumulation of cytoplasmic lipid droplets in 3T3-L1 cells", Phytomedicine, 20 (6), 481-7 (2013). 
34- C. Li and L. Zhou, "Inhibitory effect 6gingerol on adipogenesis through activation of the $\mathrm{Wnt} / \beta$-catenin signaling pathway in 3T3-L1 adipocytes", Toxicology in Vitro, 30 (1), 394-401 (2015).

35- P. Randle, P. Garland, C. Hales and E. Newsholme, "The glucose fatty-acid cycle its role in insulin sensitivity and the metabolic disturbances of diabetes mellitus", The Lancet, 281 (7285), 785-9 (1963).

36- A. Shah, N. Mehta and M. P. Reilly, "Adipose inflammation, insulin resistance, and cardiovascular disease", J. Parenter. Enteral Nutr., 32 (6), 638-44 (2008).

37- H-F. Liang, B. Yin, H. Zhang, S. Zhang, Q. Zeng, J. Wang, et al., "Blockade of Tumor Necrosis Factor (TNF) Receptor Type 1-Mediated TNF Signaling Protected Wistar Rats from Diet-Induced Obesity and Insulin Resistance", Endocrinology, 2943-51 (2008).

38.- V. Kothari, Y. Luo, T. Tornabene, A. M. O'Neill, M. W. Greene, T. Geetha, et al., "High fat diet induces brain insulin resistance and cognitive impairment in mice", Biochimica et Biophysica Acta Molecular Basis of Disease, 1863 (2), 499-508 (2017).

39- J. Zhu, H. Chen, Z. Song, X. Wang and Z. Sun, "Effects of ginger (Zingiber officinale Roscoe) on type 2 diabetes mellitus and components of the metabolic syndrome: A systematic review and metaanalysis of randomized controlled trials", Evid. Based Complement. Alternat. Med., 2018, (2018).

40- D. Patel, S. Prasad, R. Kumar and S. Hemalatha, "An overview on antidiabetic medicinal plants having insulin mimetic property", Asian Pac. J. Trop. Biomed., 2 (4), 320-30 (2012).

41- N. Maharlouei, R. Tabrizi, K. B. Lankarani, A. Rezaianzadeh, M. Akbari, F. Kolahdooz, et al., "The effects of ginger intake on weight loss and metabolic profiles among overweight and obese subjects: A systematic review and metaanalysis of randomized controlled trials", Critical reviews, Food Sci. Nutr., 1-14 (2018).

42- B. O. Iranloye, A. P. Arikawe, G. Rotimi and A. O. Sogbade, "Anti-diabetic and anti-oxidant effects of Zingiber officinale on alloxan-induced and insulin-resistant diabetic male rats", Niger. J. Physiol. Sci., official publication of the Physiological Society of Nigeria, 26 (1), 89-96 (2011).

43- M. da Silveira Vasconcelos, E. F. Mota, N. F. Gomes-Rochette, D. C. S. NunesPinheiro, S. M. Nabavi and D. F. de Melo, "Ginger (Zingiber officinale Roscoe). Nonvitamin and Nonmineral Nutritional Supplements", Elsevier, 2019, pp. 235-9.

44- S. R. Nagarajan, A. E. Brandon, J. A. McKenna, H. C. Shtein, T. Q. Nguyen, E. Suryana, et al. "Insulin and diet-induced changes in the ubiquitin-modified proteome of rat liver", PloS One., 12 (3), e0174431 (2017).

45- A. Ferron, F. Francisqueti, I. Minatel, C. Silva, S. Bazan, K. Kitawara, et al., "Association between Cardiac Remodeling and Metabolic Alteration in an Experimental Model of Obesity Induced by Western Diet", Nutrients, 10 (11), 1675 (2018).

46- A. R. Saltiel and C. R. Kahn,. "Insulin signalling and the regulation of glucose and lipid metabolism", Nature, 414 (6865), 799 (2001).

47- Y. Yamamoto and A. Yasuoka, "Welsh onion attenuates hyperlipidemia in rats fed on high-fat high-sucrose diet", Biosci. Biotechnol. Biochem., 0912261791 (2010).

48- S. Nammi, S. Sreemantula and B. D. Roufogalis, "Protective effects of ethanolic extract of Zingiber officinale rhizome on the development of metabolic syndrome in high-fat diet-fed rats", Basic Clin. Pharmacol. Toxicol., 104 (5), 36673 (2009).

49- A. J. Akinyemi, G. Oboh, A. O. Ademiluyi, A. A. Boligon and M. L. Athayde, "Effect of two ginger varieties on arginase activity in hypercholesterolemic rats", J. Acupunct. Meridian Stud., 9 (2), 80-7 (2016).

50- M. Khosravani, M. Azarbayjani, M. Abolmaesoomi, A. Yusof, N. Z. Abidin, E. Rahimi, et al., "Ginger extract and aerobic training reduces lipid profile in high-fat fed diet rats", Eur. Rev. Med. Pharmacol. Sci., 20 (8), 1617-22 (2016).

51- J. Tang, H. Yan and S. Zhuang, "Inflammation and oxidative stress in 
obesity-related glomerulopathy", Int. J. Nephrol., 2012, (2012).

52- A. Rosas-Villegas, M. Sánchez-Tapia, A. Avila-Nava, V. Ramírez, A. Tovar and N. Torres, "Differential effect of sucrose and fructose in combination with a high fat diet on intestinal microbiota and kidney oxidative stress", Nutrients, 9 (4), 393 (2017).

53- I. Grgic, G. Campanholle, V. Bijol, C. Wang, V. S. Sabbisetti, T. Ichimura, et al., "Targeted proximal tubule injury triggers interstitial fibrosis and glomerulosclerosis", Kidney Int., 82 (2), 172-83 (2012).
54- S. A. Gabr, A. H. Alghadir and G. A. Ghoniem, "Biological activities of ginger against cadmium-induced renal toxicity", Saudi J. Biol. Sci., (2017).

55- M. Mehrdad, M. Messripour and M. Ghobadipour, "The effect of ginger extract on blood urea nitrogen and creatinine in mice", Pak. J. Biol. Sci., 10, 2968-71 (2007). 


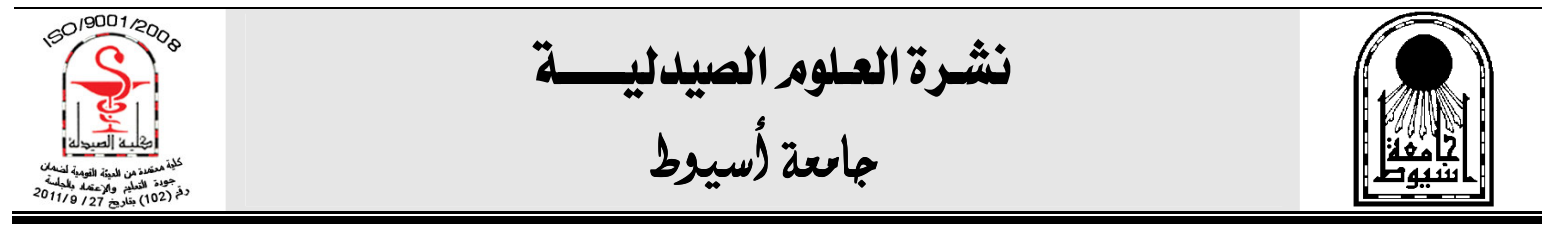

\section{خفض مستويي الجلوكوز و الدهون بو اسطة الزنجبيل يحسن وظائف الكلى في ذكور الجرذان المسمنة}

أميرة مصطفي النويهي' - نجلاء طه المليجي' - سالي محمد بكار ' - شيماء عبد الناصر' '

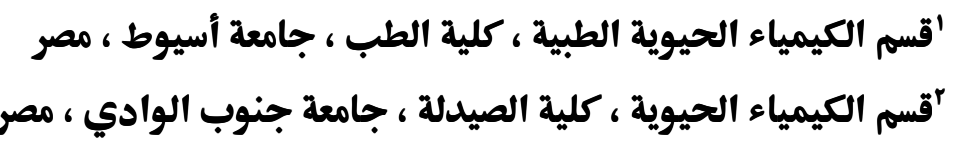

ترتبط السمنة في كثير من الأحيان بمقاومة الأنسولين، وبدور ها بتطور مرض الـسكري متسن

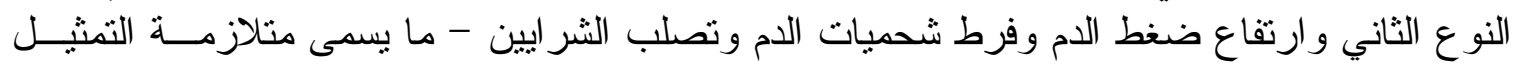

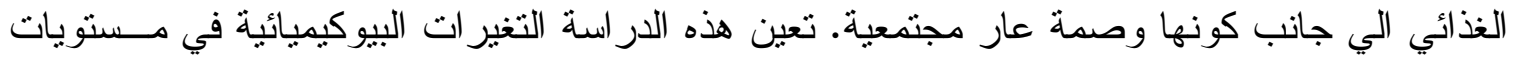

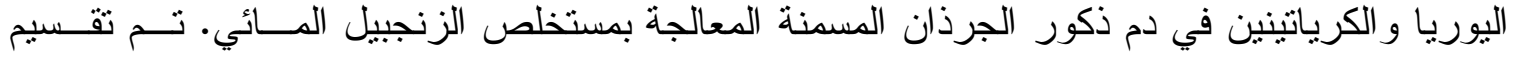

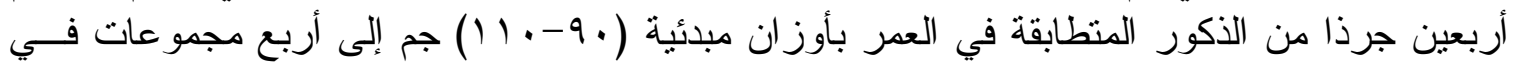

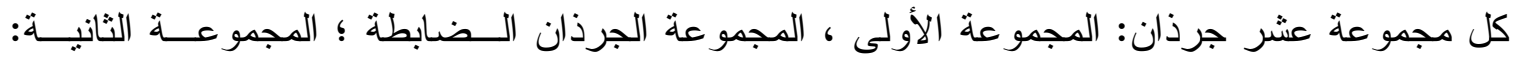

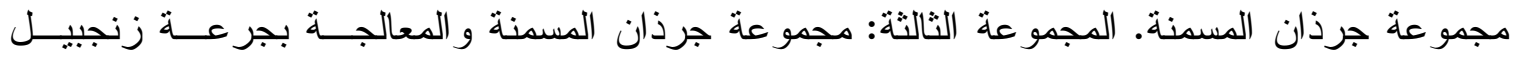

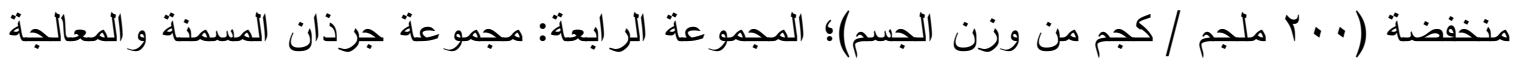

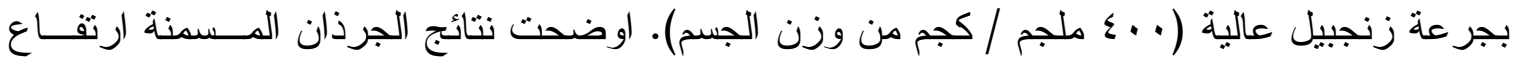

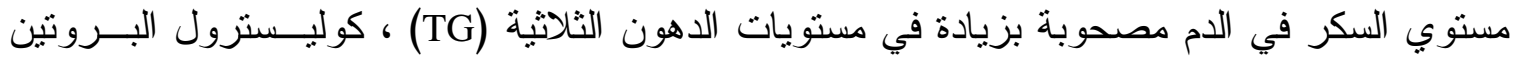

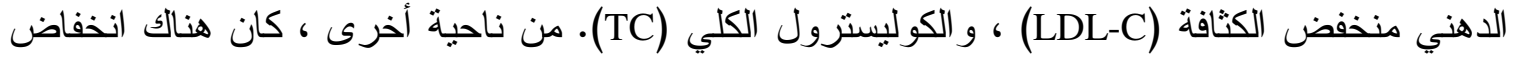

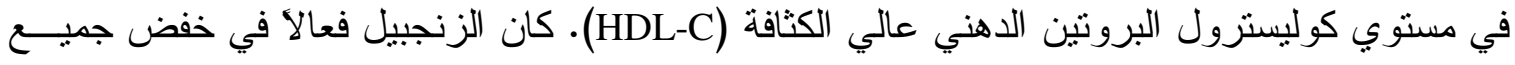

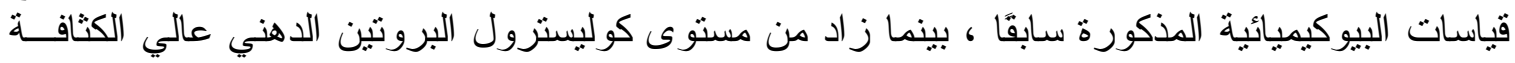

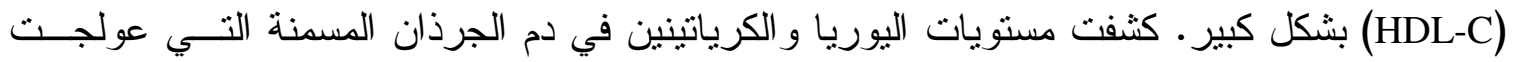

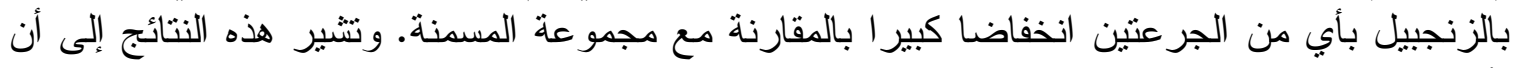

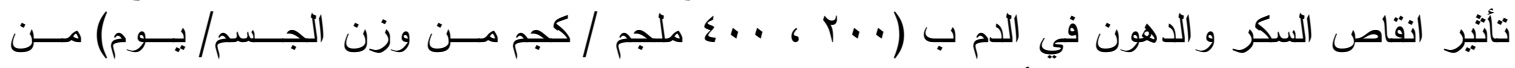
مستخلص الزنجبيل المائي يمكن أن يخفف من اختلال وظائف الكلى المرتبط بالسمنة. 